\title{
Effect of a metabolically created systemic acidosis on calcium homeostasis and the diurnal variation in urine $\mathrm{pH}$ in the non-lactating pregnant dairy cow
}

\author{
John R Roche ${ }^{1 *}$, Dawn E Dalley ${ }^{2}$ and Frank P O'Mara ${ }^{3}$ \\ ${ }^{1}$ University of Tasmania, Burnie, Tasmania, Australia 7320 \\ ${ }^{2}$ Dexcel Ltd., Hamilton, New Zealand \\ ${ }^{3}$ UCD School of Agriculture, Food Science and Veterinary Medicine, University College Dublin, Belfield, Dublin 4, Ireland
}

Received 16 March 2006 and accepted for publication 1 June 2006

\begin{abstract}
Reducing the dietary cation-anion difference (DCAD) has been shown to be an effective means of preventing parturient paresis in confinement systems where cows are offered a total mixed ration containing DCAD-reducing mineral compounds (anionic salts). Such a supplementation strategy is not possible in cows being group fed forages precalving, and little is known about the effect of supplementing these cows with large amounts of anionic salts twice daily.

Eight non-lactating, pregnant Holstein-Friesian cows were allocated to two levels of DCAD $(-20$ and $+18 \mathrm{meq} / 100 \mathrm{~g} \mathrm{DM})$ for $24 \mathrm{~d}$, with an intensive Ca balance undertaken in metabolism stalls following a 2-week acclimatization to diet. The basal diet was $3 \mathrm{~kg}$ DM of crushed barley and $7 \mathrm{~kg}$ DM of pasture-hay. Urine and faeces were collected separately, weighed daily for $5 \mathrm{~d}$ and analysed for $\mathrm{Ca}$ content. Urinary $\mathrm{Ca}$, creatinine and hydroxyproline concentration and plasma Ca concentration were determined during the period of the balance study. The diurnal pattern in urine and rumen $\mathrm{pH}$ was determined over $2 \mathrm{~d}$. Decreasing DCAD reduced $(P<0 \cdot 001)$ the $\mathrm{pH}$ of urine, and increased $(P<0.05) \mathrm{Ca}$ absorption. Plasma Ca concentration was not affected by DCAD, and DCAD did not affect the output of urinary hydroxyproline, a marker of bone resorption. Twice-daily supplementation of anionic salts was sufficient to reduce the $\mathrm{pH}$ of blood and increase gastrointestinal $\mathrm{Ca}$ absorption. There was no diurnal variation in the $\mathrm{pH}$ of urine, suggesting that time of sampling to determine efficacy of DCAD in reducing systemic $\mathrm{pH}$ was not important.
\end{abstract}

Keywords: Dietary cation-anion difference, anionic salts, $\mathrm{pH}$, calcium, non-lactating dairy cows, DCAD.

In the transition from pregnancy to lactation, clearance of Ca to the placenta ceases but the lactational Ca demand increases rapidly (Ramberg et al. 1984). Hypocalcaemia develops in most cows owing to this demand and, if blood Ca becomes insufficient to support nerve and muscle function, parturient paresis (milk fever; MF) results (Schultz et al. 1988; Goff \& Horst, 1997).

Following analysis of 30 years' data, Roche \& Berry (2006) concluded that MF incidence in pasture systems approximated $2-3 \%$, but varied greatly from year to year and was influenced by climate and cow factors such as condition score, parity and breed. The disorder was first reported in Germany in 1793 (Schultz et al. 1988) and has since been a well-researched subject because of its economic importance. Block (1984) reported a $14 \%$ and $7 \%$

*For correspondence; e-mail: john.roche@utas.edu.au reduction in milk yield in cows that experienced clinical and subclinical parturient hypocalcaemia, respectively, and Belonje \& Van der Walt (1971) reported poorer fertility (prolonged inter-calving period) in cows that contracted MF. In addition, Schultz et al. (1988) reported a mortality rate of $3 \cdot 5-5 \%$ in clinically affected cows, and observed that productive life of affected cows was reduced by approximately 3.5 years. Similarly, Cox (1981) reported that $4-28 \%$ of cases of MF relapse and may become downer cows. Of those affected, 20-67\% die subsequently or must be slaughtered.

MF control strategies vary (see reviews by Horst et al. 1997; Roche, 2003) and include the feeding of a precalving diet containing a low Ca concentration (Wiggers et al. 1975; Littledike \& Goff, 1987), supplementation with Mg precalving (Lean et al. 2006) and/or supplementation of Ca at calving (Roche et al. 2002, 2003b). These treatments reflect the belief that dietary Ca concentration, either too 
great precalving or insufficient availability postcalving, is the principal determinant of a cow's susceptibility to parturient hypocalcaemia.

Although these nutritional practices have dramatically reduced the incidence of MF (Roche \& Berry, 2006), they have failed to eradicate it. More recently, the relative importance of precalving dietary $\mathrm{Ca}$ has come under review (Oetzel, 1991; Goff \& Horst, 1997; Lean et al. 2006), and it has been proposed that it may not be as important a risk factor as high intakes of $\mathrm{K}$ and $\mathrm{Na}$ precalving, and their effects on blood acid-base status (Goff \& Horst, 1997). Changes in blood $\mathrm{pH}$ affect Ca metabolism (Bushinsky et al. 1993). A precalving diet with a relative predominance of $\mathrm{S}$ and $\mathrm{Cl}$ (anions) to $\mathrm{Na}$ and $\mathrm{K}$ (cations; i.e. a negative dietary cation-anion difference or DCAD) has been shown to reduce blood $\mathrm{pH}$ in pasture-based cows (Roche et al. 2003a), and increase the absorption (Schonewille et al. 1994) and urinary excretion of $\mathrm{Ca}$ (Vagg \& Payne, 1970; Vagnoni \& Oetzel, 1998).

An issue peculiar to the management of cows fed forage precalving is the inability to mix the required mineral compounds with the base-feed. Roche et al. (2003a,b) administered mineral compounds via a drench twice daily. Little is known about the efficacy of these compounds when supplemented twice daily, compared with throughout the day as in systems using total mixed rations. Similarly, the effect of twice-daily supplementation on the diurnal variation in the $\mathrm{pH}$ of urine and rumen fluid requires investigation. The objective of the work reported here was to examine the effect of a reduced DCAD on Ca absorption, and the amount of $\mathrm{Ca}$ and hydroxyproline excreted by the non-lactating pregnant dairy cow.

\section{Materials and Methods}

The experiment was conducted at Agriculture Victoria Ellinbank $\left(37^{\circ} 50^{\prime} \mathrm{S}, 145^{\circ} 00 \mathrm{E}\right)$, approximately $110 \mathrm{~km}$ east of Melbourne, Australia, in May-June 1999. All procedures in this study were approved by the Ellinbank Animal Ethics Committee and animals were handled according to the Code of Practice for the Care and Use of Animals for Experimental Purposes.

\section{Experimental design, feeding and treatments}

Eight multiparous, non-lactating, $220 \pm 7$ d pregnant, rumenfistulated Holstein-Friesian cows were randomly allocated to two DCAD treatments (High and Low), ensuring groups were balanced for age $(5 \cdot 8 \pm 0 \cdot 44$ years) and liveweight $(584 \pm 52 \mathrm{~kg})$. The use of non-lactating dairy cows that are not near calving does not allow direct extrapolation of results to parturition, but findings can be interpreted physiologically and are therefore important.

All cows were offered a restricted daily diet of $3 \mathrm{~kg} D M$ of crushed barley and $7 \mathrm{~kg}$ DM pasture-hay (predominantly Lolium perenne L.). This is a diet not untypical of what is offered to dairy cows in Australia and New Zealand around parturition, when pasture growth rates are insufficient to meet cow demands. The barley was individually fed, in two feeds, at 09.00 and 15.00 and the hay was fed once a day at 09.30. Cows had approximately 12-h access to their hay allocation. Water was available ad libitum and water intake was recorded thrice daily.

Cows on the Low DCAD treatment were supplemented with $200 \mathrm{~g} \mathrm{MgCl}_{2} \cdot 6 \mathrm{H}_{2} \mathrm{O}$ and $100 \mathrm{~g} \mathrm{NH}_{4} \mathrm{Cl}$ to reduce the DCAD to $-20 \mathrm{meq} / 100 \mathrm{~g}$ DM. DCAD was calculated using the equation:

$$
\begin{aligned}
\operatorname{DCAD}(\mathrm{meq} / 100 \mathrm{~g} \mathrm{DM})= & (\mathrm{Na} / 0 \cdot 023)+(\mathrm{K} / 0 \cdot 039) \\
& -(\mathrm{Cl} / 0 \cdot 0355)-(\mathrm{S} / 0 \cdot 016)
\end{aligned}
$$

where dietary mineral concentration is expressed as \% DM.

To ensure that treatments did not differ in their dietary Mg concentration (0.5\% DM), High DCAD cows were supplemented with $60 \mathrm{~g} \mathrm{MgO}$. Cows received their appropriate mixture of mineral compounds twice daily at 09.00 and 15.00 via the rumen fistula.

\section{Measurements}

Background measurements of urine $\mathrm{pH}$ and $\mathrm{Ca}$ and creatinine concentrations were taken on all animals prior to beginning the experiment. Cows were allowed to adapt to their respective treatments for $14 \mathrm{~d}$ (acclimatization period; days 1-14), following which the cows were individually fed indoors in metabolism stalls $(2 \mathrm{~m} \times 1.3 \mathrm{~m})$ for $9 \mathrm{~d}$ (days 15-23). Cows were allowed access to their barley for $15 \mathrm{~min}$ at 9.00 and 15.00 before being allowed access to hay until 21.30. Days 15 and 16 were conditioning days for the cows to become accustomed to the stalls. On day 16 the cows were fitted with a harness to facilitate separation of urine and faeces. The intensive Ca balance monitoring period ran from days 17-21. Days 22, 23 and 24 were used for intensive monitoring of the $\mathrm{pH}$ of urine and ruminal contents.

During the $4 \mathrm{~d}$ prior to the start of the experiments (covariate period; days -3 to 0 ), the $14-d$ acclimatization period outdoors, the first $2 \mathrm{~d}$ of the metabolism stall period (days 15 and 16) and on days 22-24, cows were manually stimulated to urinate at 9.00, and a sample of urine was collected from midstream in a 50-ml sterile container. Within $30 \mathrm{~min}$ of collection, the $\mathrm{pH}$ was determined and representative subsamples analysed for $\mathrm{Ca}$ and creatinine, respectively.

During the Ca balance period (days 17-21), faeces and urine were collected separately in plastic containers. The weight of faeces and the volume of urine voided during the previous $24 \mathrm{~h}$ were recorded at 9.00 daily. Faeces were thoroughly mixed and samples dried at $105^{\circ} \mathrm{C}$ and $65{ }^{\circ} \mathrm{C}$ for DM and Ca determination, respectively. After mixing, the $\mathrm{pH}$ of urine was determined and samples analysed for $\mathrm{Ca}$, hydroxyproline and creatinine. 
Table 1. Mean dry matter (DM, \% fresh weight), crude protein (CP), dry matter digestibility in vitro (DMD), metabolizable energy $(\mathrm{ME} ; \mathrm{MJ} / \mathrm{kg} \mathrm{DM})$, dietary cation-anion difference (DCAD; meq/100 g DM) and mineral concentrations (\% DM, unless stated otherwise) of the feeds offered to non-lactating dairy cows

$\begin{array}{lccccccccrrrr}\text { Feed } & \text { DM } & \text { CP } & \text { ME } & \text { K } & \text { Na } & \text { Cl } & \text { S } & \text { Mg } & \text { Ca } & \text { P } & \text { DCAD } \\ \text { Hay } & 79 & 8 \cdot 6 & 8 \cdot 5 & 2 \cdot 33 & 0 \cdot 31 & 1 \cdot 30 & 0 \cdot 16 & 0 \cdot 17 & 0 \cdot 40 & 0 \cdot 21 & 26 \cdot 5 \\ \text { SD } & 3 \cdot 1 & 0 \cdot 15 & 0 \cdot 60 & 0 \cdot 12 & 0 \cdot 09 & 0 \cdot 10 & 0 \cdot 02 & 0 \cdot 01 & 0 \cdot 04 & 0 \cdot 03 & 3 \cdot 9 \\ \text { Barley } & 87 & 11 \cdot 7 & 12 \cdot 2 & 0 \cdot 50 & 0 \cdot 02 & 0 \cdot 16 & 0 \cdot 14 & 0 \cdot 11 & 0 \cdot 05 & 0 \cdot 32 & 2 \cdot 2 \\ \text { SD } & 1 \cdot 0 & 0 \cdot 15 & 0 \cdot 08 & 0 \cdot 06 & - & 0 \cdot 03 & 0 \cdot 02 & 0 \cdot 01 & 0 \cdot 01 & 0 \cdot 02 & 0 \cdot 7 \\ \text { Diet } & 82 \cdot 4 & 9 \cdot 6 & 9 \cdot 7 & 1 \cdot 76 & 0 \cdot 30 & 1 \cdot 07 & 0 \cdot 16 & 0 \cdot 15 & 0 \cdot 34 & 0 \cdot 22 & 18 \cdot 1 \\ \text { SD } & 2 \cdot 73 & 0 \cdot 29 & 0 \cdot 29 & 0 \cdot 10 & 0 \cdot 02 & 0 \cdot 06 & 0 \cdot 01 & 0 \cdot 01 & 0 \cdot 02 & 0 \cdot 01 & 1 \cdot 08\end{array}$

One evacuated blood tube containing a sodium heparin pellet (100 i.u. sodium heparin/ml blood), to prevent coagulation, was collected by jugular venipuncture daily from each cow during the Ca balance period. Plasma was extracted by centrifuging at $1120 \mathrm{~g}$ at $4{ }^{\circ} \mathrm{C}$ for $10 \mathrm{~min}$ and analysed for Ca content.

Urine, faecal and plasma Ca concentrations were determined against a series of Ca standards by atomic absorption spectrophotometry (Perkin Elmer 372, Rodgau-Jügesheim, Germany) at $422 \cdot 7 \mathrm{~nm}$. Urine hydroxyproline was determined on a microplate reader (Biorad 550, Hercules CA, USA; Parekh \& Jung, 1970) and urinary creatinine was measured using an autoanalyser (Boehringer Manheim Hitachi 911, Mannhein 31, Germany) as described by Bartels et al. (1972).

Daily intake was recorded for each cow and representative samples (approximately $200 \mathrm{~g}$ ) of each feed offered and refused were dried at $105^{\circ} \mathrm{C}$ for $24 \mathrm{~h}$ to determine DM content and calculate DM intake (DMI) by difference. Daily samples of all feeds offered were bulked weekly during the 14-d acclimatization and over the $9 \mathrm{~d}$ of the indoor intensive measurement period, dried at $65{ }^{\circ} \mathrm{C}$ for $72 \mathrm{~h}$, ground to pass through a $0 \cdot 5-\mathrm{mm}$ sieve, and analysed for macrominerals, DM digestibility in vitro (DMD) and nitrogen. Macrominerals were determined using x-ray spectroscopy (Hutton \& Norrish, 1977; Norrish \& Hutton, 1977). DMD was determined by the method of Clarke et al. (1982) and N content was determined by Kjeldahl using an automated Tecator instrument, (Foss, Denmark; Association of Official Analytical Chemists, 1990). Metabolizable energy $(\mathrm{ME})$ was calculated from $\mathrm{DMD}(\mathrm{ME}=\mathrm{DMD} \times 0 \cdot 17$; Standing Committee on Agriculture, 1990) and crude protein was calculated from $\mathrm{N}$ (Crude protein $=\mathrm{N} \times 6 \cdot 25$ ). Nutritive characteristics and mineral concentrations of the feeds offered are presented in Table 1.

\section{Intensive rumen and urine sampling}

Urine and rumen samples were taken at 8.00, 12.00, 16.00, 20.00 and 24.00 day 22, 4.00, 6.00, 10.00, 14.00, 18.00 and 22.00 on day 23 and 2.00 and 6.00 on day 24 . Urine samples were obtained by perineal stimulation for up to $10 \mathrm{~min}$. Samples could not be obtained on six occasions. A representative sample $(50 \mathrm{ml})$ of ruminal fluid
Table 2. Effect of dietary cation-anion difference (DCAD) on the daily dry matter intake (DMI) (kg DM/cow), water imbibed daily (l/cow), daily outputs of faeces (kg DM/cow) and urine (l/cow), daily faecal water output $(\mathrm{kg} / \mathrm{cow})$ and dry matter digestibility in vivo (IVDMD; \%) of non-lactating pregnant dairy cows

$\begin{array}{lccll} & \text { High } & \text { Low } & & P \\ & \text { DCAD } & \text { DCAD } & \text { SED } & \text { value } \\ \text { DMI } & 9 \cdot 3 & 9 \cdot 2 & 0 \cdot 54 & 0 \cdot 82 \\ \text { Water imbibed } & 36 \cdot 3 & 39 \cdot 9 & 2 \cdot 16 & 0 \cdot 13 \\ \text { Faecal output } & 3 \cdot 2 & 3 \cdot 5 & 0 \cdot 42 & 0 \cdot 49 \\ \text { Faecal water } & 23 \cdot 2 & 25 \cdot 3 & 1 \cdot 53 & 0 \cdot 21 \\ \text { Urine output } & 15 \cdot 0 & 13 \cdot 3 & 2 \cdot 74 & 0 \cdot 55 \\ \text { IVDMD } & 61 \cdot 0 & 60 \cdot 4 & 4 \cdot 17 & 0 \cdot 87\end{array}$

was obtained from three sites in the rumen (anterior, central and posterior) approximately equidistant between the dorsal and ventral surfaces, through a 500-mm copper pipe (10-mm diameter with $5-\mathrm{mm}$ holes in the last $80 \mathrm{~mm}$ ) attached to a 50-ml syringe. The $\mathrm{pH}$ of urine and ruminal fluid was measured within 30 min of collection using a Metrohm $827 \mathrm{pH}$ meter (Metrohm, Herisau, Switzerland).

\section{Calculations and statistical analysis}

Urinary Ca concentration was expressed as a ratio to creatinine concentration, providing a corrected urinary Ca concentration (CUCa) to overcome variations in urine volume between animals (Roche et al. 2003a).

All data were analysed using Analysis of Variance (Genstat V, 1997) with cows as a random effect and DCAD as a fixed effect. Repeated measurements through time were modelled using spline models within the linear mixed model framework. There was an interaction with time and so individual time points are presented for ease of interpretation.

\section{Results and Discussion}

DMI, water imbibed and urine and faecal output were not affected by DCAD treatment (Table 2).

Treatments were implemented successfully, with DCAD of -20 and $+18 \mathrm{meq} / 100 \mathrm{~g}$ DM consumed on the low and high DCAD treatments, respectively. Further proof was the decline $(P<0 \cdot 001)$ in urine $\mathrm{pH}$ on the low DCAD 
Table 3. Effect of dietary cation-anion difference (DCAD) on the urine $\mathrm{pH}$, net $\mathrm{Ca}$ balance $(\mathrm{g} \mathrm{Ca} / \mathrm{cow}$ per $\mathrm{d}$, unless stated otherwise) and urinary hydroxyproline output of non-lactating pregnant dairy cows

$\begin{array}{lcclc} & \text { High } & \text { Low } & & \\ & \text { DCAD } & \text { DCAD } & \text { SED } & P \text { value } \\ \text { Urine } \mathrm{pH} & 8 \cdot 5 & 5 \cdot 7 & 0 \cdot 05 & <0 \cdot 001 \\ \text { Ca intake } & 28 & 28 & 1 \cdot 48 & 0 \cdot 64 \\ \text { Urine Ca } & 0 \cdot 8 & 5 \cdot 3 & 0 \cdot 69 & 0 \cdot 001 \\ \text { Faecal Ca } & 46 & 37 & 3 \cdot 3 & 0 \cdot 04 \\ \text { Total Ca excreted } & 47 & 43 & 3 \cdot 44 & 0 \cdot 26 \\ \text { Ca retention } & -19 & -14 & 3 \cdot 23 & 0 \cdot 17 \\ \text { Plasma Ca, mmol/I } & 2 \cdot 50 & 2 \cdot 45 & 0 \cdot 058 & 0 \cdot 31 \\ \text { Urinary hydroxyproline, } & 8 \cdot 7 & 7 \cdot 4 & 1 \cdot 13 & 0 \cdot 29\end{array}$

treatment the day following treatment initiation. There was no difference in the intake of Ca between treatments. However, faecal Ca output was decreased $(P<0 \cdot 05)$ and urinary Ca output was increased $(P<0.001)$ on the lower DCAD diet, suggesting that gastrointestinal absorption of Ca was improved through the daily provision of anionic salts in two equal doses. The increased absorption did not affect plasma Ca (Table 3).

Schonewille et al. (1994) also found an increased absorption of $\mathrm{Ca}$ when anionic salts were fed, but reported that only $60 \%$ of increased urinary Ca output could be accounted for by increased absorption. As a result many researchers have postulated that bone resorption may be contributing the Ca unaccounted for by absorption into the excreted Ca pool. In support of this premise, Fredeen et al. (1988) showed that rates of $\mathrm{Ca}$ absorption and resorption were elevated in goats made acidotic. Schonewille et al. (1994), however, reported no effect of DCAD on markers of bone resorption. In the present experiment the reduction in faecal Ca output was greater than the increase in $\mathrm{Ca}$ excreted in urine, and the urinary output of hydroxyproline (an accepted marker of bone resorption; Russell, 1997) was not affected by treatment $(P=0 \cdot 29)$. These results suggest a lack of effect of DCAD on bone resorption, and support our earlier findings (Roche et al. 2003a, b) in dairy cows and the results presented by Chu et al. (1975) and Kim \& Linkswiler (1979) in man. The reason for the inconsistency in the reported effect of DCAD on bone resorption is unclear. Factors, such as the stage of gestation or milk yield may contribute to the variable results reported. One reason in particular may be that urinary hydroxyproline represents only $10 \%$ of hydroxyproline released (Liesegang, 2003) and can result from the degradation of tissues other than bone. It is therefore not specific to bone and study results must be considered individually and with caution, particularly in the periparturient cow when tissue catabolism may be contributing significant amounts of hydroxyproline to the pool being excreted. However, because cows in the study reported here were non-lactating, in good health, and at least 2 months precalving, and because at least half of body collagen resides in bone, where its turnover is faster than in soft tissues (Garnero \& Delmas, 1996), we are confident that use of hydroxyproline concentration in urine is an appropriate index of bone resorption. Further research is required to understand the extenuating factors affecting bone resorption and accretion under acidotic conditions.

Urine $\mathrm{pH}$ over the experimental period averaged $( \pm \mathrm{SD})$ $8 \cdot 4( \pm 0 \cdot 22)$ and $6 \cdot 4( \pm 0 \cdot 81)$ on high and low DCAD treatments, respectively, and were consistent with the mean urine $\mathrm{pH}$ predicted from the meta-analysis of Spanghero et al. (2004). However the difference in urine $\mathrm{pH}$ varied with time. Figure 1 depicts the change in urine $\mathrm{pH}$ and CUCa during the experimental period. The $\mathrm{pH}$ of urine declined for $2 \mathrm{~d}$ following initiation of the low DCAD treatment, reached a plateau, and on day 6 increased from 5.98 to $7 \cdot 83$. Urine $\mathrm{pH}$ over this period averaged $8 \cdot 2( \pm 0 \cdot 25)$ and $7 \cdot 1( \pm 0 \cdot 82)$ on high and low DCAD treatments, respectively. This rise in urine $\mathrm{pH}$ is consistent with a similar trend reported by Goff \& Horst (1998). They reported an initial decline in urine $\mathrm{pH}$ following supplementation of cows with anionic salts, and a subsequent increase in urine $\mathrm{pH}$, which they attributed to buffering of cations released from bone under acidotic conditions. On day 9 of the current study, the $\mathrm{pH}$ began to decline again to a trough of approximately $5 \cdot 5$ at day 19 (average \pm SD urine $\mathrm{pH}$ after day 9 was $8 \cdot 5 \pm 0 \cdot 12$ and $6 \cdot 0 \pm 0 \cdot 56$ on high and low DCAD treatments, respectively). Data reported by Goff \& Horst (1998) did not extend beyond day 9 and so it is not possible to say whether their data would have followed a similar trend to those reported here.

Figure 1 shows a concomitant rise in CUCa with declining $\mathrm{pH}$. However, as for $\mathrm{pH}$, the effect of DCAD on CUCa was inconsistent during the first $8 \mathrm{~d}$ of treatment, and the association between urine $\mathrm{pH}$ and CUCa was weak $\left(R^{2}=0.04\right)$ and non-significant $(P=0.58)$. However, after day 9 there was a strong $\left(R^{2}=0.81 ; C U C a=-0.47 \times\right.$ Urine $\mathrm{pH}+3.65 ; \mathrm{P}<0.001)$ negative relationship between urine $\mathrm{pH}$ and CUCa. These results suggest that there is a minimum period (approximately $9 \mathrm{~d}$ ) of low DCAD required to ensure that $\mathrm{Ca}$ absorption has increased and that cows are at a reduced risk of milk fever. This is consistent with the output of a recent meta analysis (Lean et al. 2006) that showed a significant effect of exposure to a transition ration containing anionic salts on the reduction in the odds of milk fever occurring.

Figure 2 shows the effect of a high or low DCAD on the $\mathrm{pH}$ of urine and rumen fluid throughout the day. The lack of effect of DCAD on the pH of ruminal contents is in contrast to the findings of Tucker et al. (1988a) who reported a linear decline in the $\mathrm{pH}$ of ruminal fluid with decreasing DCAD from +20 to $-20 \mathrm{meq} / 100 \mathrm{~g}$ DM. In the work reported here it appears that, although very little variation occurred, the minimum urine $\mathrm{pH}$ (the maximum response to a decreasing DCAD) occurred approximately 3-4 h after feeding anionic salts, supporting the earlier work of Tucker et al. (1988b). However, the variation was small. 


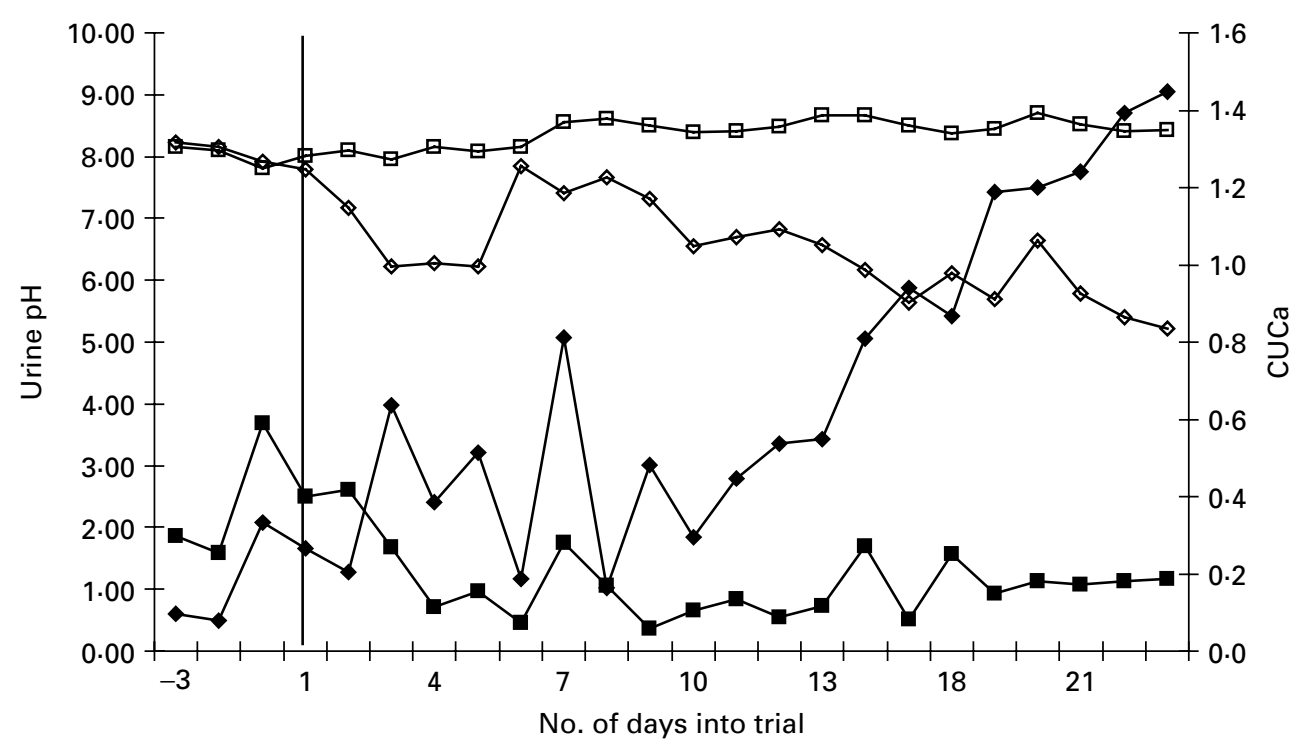

Fig. 1. Effect of a high or low dietary cation-anion difference (DCAD) on the pH of urine ( $\square$ and $\diamond=$ high and low DCAD, respectively) and the corrected urinary $\mathrm{Ca}$ concentration $(\mathrm{CUCa}$, the ratio of ratio of urine $\mathrm{Ca}$ concentration to urine creatinine concentration; and a $=$ high and low DCAD, respectively) of non-lactating pregnant dairy cows. Treatments commenced on Day 1 .

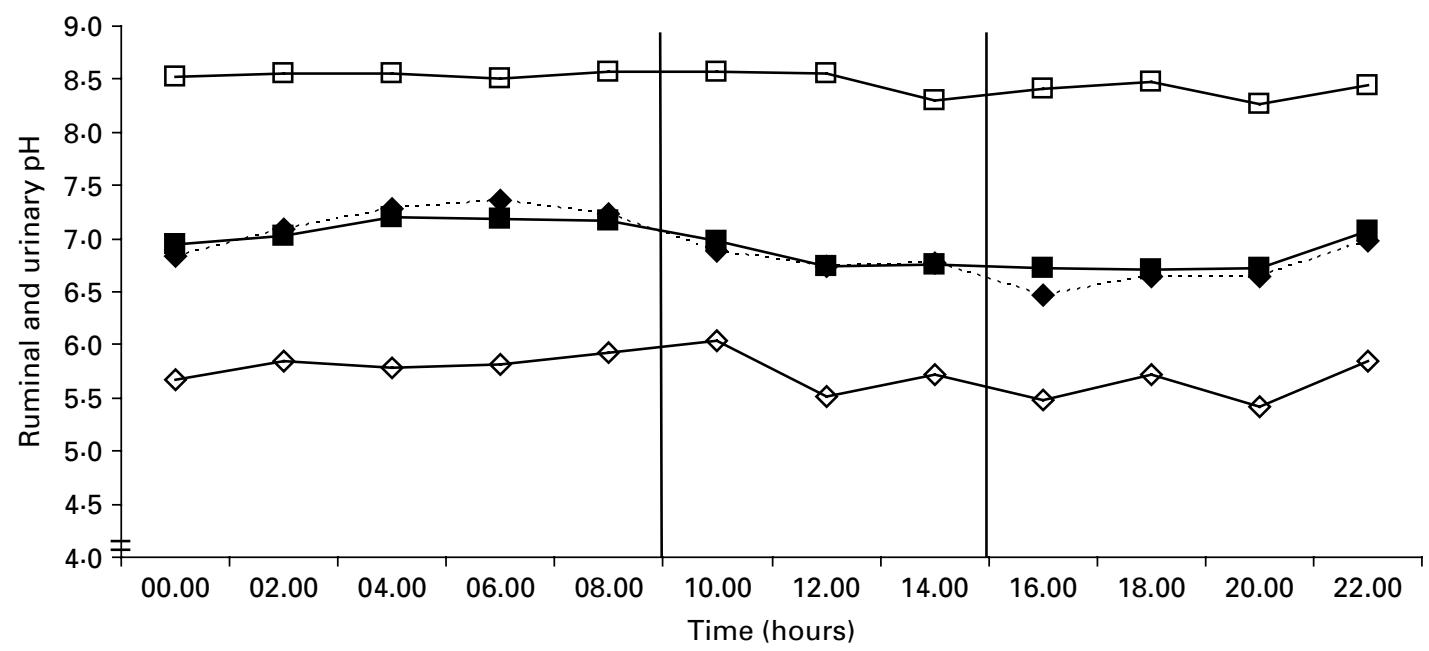

Fig. 2. The effect of a high or low dietary cation-anion difference (DCAD) on the pH of urine ( $\square$ and $\diamond=$ high and low DCAD, respectively) and ruminal fluid ( $\boldsymbol{\square}$ and $=$ high and low DCAD, respectively) of non-lactating pregnant dairy cows over a $24-\mathrm{h}$ period. Ca salts were administered at 9.00 and 15.00 .

When DCAD was maintained at $-20 \mathrm{meq} / 100 \mathrm{~g}$ DM, the $\mathrm{pH}$ of urine remained below $6 \cdot 2$ throughout the $24 \mathrm{~h}$, supporting the review of Horst et al. (1997) and the findings of Roche et al. (2003a), which claimed that urine $\mathrm{pH}$ must be maintained between 5.5 and 6.2 for the $\mathrm{pH}$ of blood to be sufficiently lowered to increase $\mathrm{Ca}$ absorption. The lack of diurnal variation in urine $\mathrm{pH}$ from cows on the low DCAD treatment is also an important finding, highlighting that the desired reduction in systemic $\mathrm{pH}$ can be achieved in forage-based systems (indoors and grazing) through twice daily supplementation with anionic salts. It also suggests that if a reduction in DCAD is being used to reduce periparturient hypocalcaemia, urine $\mathrm{pH}$ can be measured at any time of the day to ascertain whether DCAD has been reduced sufficiently to alter blood $\mathrm{pH}$.

\section{Conclusions}

A low DCAD ( $-20 \mathrm{meq} / 100 \mathrm{~g}$ DM) caused a metabolic systemic acidosis and an increase in Ca absorption, but did not appear to affect bone resorption. The $\mathrm{pH}$ of ruminal contents was unaffected by the reduced DCAD. The $\mathrm{pH}$ of urine was reduced by the low DCAD and remained relatively constant throughout the day. This suggests that if anionic salts are being offered twice daily, the $\mathrm{pH}$ of urine 
can be tested at any time of day to determine the efficacy of the daily ration in reducing the $\mathrm{pH}$ of blood. It also suggests that a urinary $\mathrm{pH}$ below $6 \cdot 2$ is a good indicator that DCAD has been reduced to the recommended levels of -15 to $-20 \mathrm{meq} / 100 \mathrm{~g}$ DM.

The authors acknowledge the technical assistance of Glenn Lineham, Karen Baum, Diane Mapleson, Debbie Wilson, Ian Robinson, Jack and Sue Laidlaw and Marg Davies of Agriculture Victoria, and Jimmy Callan of University College Dublin. The authors also wish to thank farm staff for all the help afforded them.

\section{References}

Association of Official Analytical Chemists 1990 Crude protein determination in animal feed: copper catalyst Kjeldahl method (984.13). In Official Methods of Analysis of AOAC International. Arlington VA, USA: AOAC International

Bartels H, Boemer M \& Heirli C 1972 Serum creatinine determination without deproteinization. Clinica Chimica Acta 37 193-197

Belonje PC \& Van der Walt K 1971 Milk fever in a large Jersey herd. 1. The incidence of the condition. Journal of the South African Veterinary Medicine Association 42 135-141

Block E 1984 Manipulating dietary anions and cations for prepartum dairy cows to reduce incidence of milk fever. Journal of Dairy Science 67 2939-2948

Bushinsky DA, Wolbach W, Sessler N, Mogilevsky R \& Levi-Setti R 1993 Physicochemical effects of acidosis on bone calcium flux and surface ion composition. Journal of Bone Mineral Research 8 93-102

Chu JY, Margen S \& Costa FM 1975 Studies in calcium metabolism. 2. Effects of low calcium and variable protein intake on human calcium metabolism. American Journal of Clinical Nutrition 28 1028-1035

Clarke T, Flinn PC \& McGowan AA 1982 Low cost pepsin-cellulase assays for the prediction of digestibility of herbage. Grass and Forage Science 37 147-150

Cox VS 1981 Pathogenesis of the downer cow syndrome. In Proceedings of the British Cattle Veterinarians Association, Cheshire, England, pp. $5-13$

Fredeen AH, DePeters EJ \& Baldwin RL 1988 Effects of acid-base disturbances caused by differences in dietary fixed ion balance on kinetics of calcium metabolism in ruminants with high calcium demand. Journal of Animal Science 66 174-184

Garnero P \& Delmas PD 1996 Measurements of biochemical markers: methods and limitations. In Principles of Bone Biology, pp. 1277-1291 (Eds JP Bilezikian, LG Raisz \& GA Rodan). San Diego CA, USA: Academic Press

Genstat V 1997 Genstat 5, Release 4.1, Reference Manual. Oxford University Press, Oxford, United Kingdom

Goff JP \& Horst RL 1997 Effects of the addition of potassium or sodium, but not calcium, to prepartum rations on milk fever in dairy cows. Journal of Dairy Science $\mathbf{8 0}$ 176-186

Goff JP \& Horst RL 1998 Use of hydrochloric acid as a source of anions for prevention of milk fever. Journal of Dairy Science 81 2874-2880

Horst RL, Goff JP, Reinhardt TA \& Buxton DR 1997 Strategies for preventing milk fever in dairy cattle. Journal of Dairy Science $\mathbf{8 0}$ $1269-1280$

Hutton JT \& Norrish K 1977 Plant analyses by x-ray spectrometry. 2. Elements of atomic number greater than 20. X-Ray Spectrometry 6 $12-17$

Kim Y \& Linkswiler HM 1979 Effect of level of protein intake on calcium metabolism and on parathyroid and renal function in the adult human male. Journal of Nutrition 109 1399-1404
Lean IJ, DeGaris PJ, McNeil DM \& Block E 2006 Hypocalcemia in dairy cows: meta-analysis and dietary cation anion difference theory revisited. Journal of Dairy Science 89 669-684

Liesegang A 2003 Possibilities of monitoring bone metabolism in ruminants-an overview of the methods in use. Acta Veterinaria Scandinavica 97 23-28

Littledike ET \& Goff JP 1987 Interactions of calcium, phosphorus, magnesium and vitamin $\mathrm{D}$ that influence their status in domestic meat animals. Journal of Dairy Science 65 1727-1743

Norrish K \& Hutton JT 1977 Plant analyses by x-ray spectrometry. 1. Low atomic number elements, sodium to calcium. X-Ray Spectrometry 6 $6-11$

Oetzel GR 1991 Meta-analysis of nutritional risk factors for milk fever in dairy cattle. Journal of Dairy Science 74 3900-3912

Parekh AC \& Jung DH 1970 An improved method for determination of total hydroxyproline in urine. Biochemical Medicine 4 446-456

Ramberg CF, Johnson EK, Fargo RD \& Kronfeld DS 1984 Calcium homeostasis in cows, with special reference to parturient hypocalcaemia. American Journal of Physiology 246 698-704

Roche JR, Morton J \& Kolver ES 2002 Sulfur and chlorine play a non-acid base role in periparturient calcium homeostasis. Journal of Dairy Science 85 3444-3453

Roche JR 2003 The incidence and control of hypocalcaemia in pasturebased systems. Acta Veterinaria Scandinavica 97 141-144

Roche JR, Dalley DE, Moate PJ, Grainger C, Rath M \& O'Mara F 2003a Dietary cation-anion difference and the health and production of pasture-fed dairy cows. 2. Non-lactating periparturient cows. Journal of Dairy Science 86 979-987

Roche JR, Dalley DE, Moate PJ, Grainger C, Rath M \& O'Mara F 2003b A low DCAD precalving and calcium supplementation postcalving increase plasma calcium but not milk production in a pasture-based system. Journal of Dairy Science $\mathbf{8 6}$ 2658-2666

Roche JR \& Berry DP 2006 Periparturient climatic, animal and management factors influencing the incidence of milk fever in grazing systems. Journal of Dairy Science 89 2775-2783

Russell RGG 1997 The assessment of bone metabolism in vivo using biochemical markers. Hormone and Metabolic Research 29 138-144

Schonewille IT, Van't Klooster AT, Dirkswager A \& Bayen A 1994 Stimulatory effect of an anion (chloride)-rich ration on apparent calcium absorption in dairy cows. Livestock Production Science $\mathbf{4 0}$ 233-240

Schultz LH, Mayland HF \& Emerick RJ 1988 Metabolic problems related to nutrition. In The Ruminant Animal. Digestive Physiology and Nutrition, pp. 493-531 (Ed. DC Church). New Jersey, USA: Prentice Hall Inc

Spanghero M 2004 Prediction of urinary and blood pH in non-lactating dairy cows fed anionic salts. Animal Feed Science and Technology 116 83-92

Standing Committee on Agriculture 1990 Energy in Ruminants Feeding Standards for Australian Livestock, pp. 1-76 (Ed. Ruminants Subcommittee). Melbourne, Australia: CSIRO Publications

Tucker WB, Harrison GA \& Hemken RW 1988a Influence of dietary cation-anion balance on milk, blood, urine and rumen fluid in lactating dairy cattle. Journal of Dairy Science 71 346-354

Tucker WB, Xin Z \& Hemken RW 1988b Influence of dietary calcium chloride on adaptive changes in acid-base status and mineral metabolism in lactating cows fed a diet high in sodium bicarbonate. Journal of Dairy Science 71 1587-1597

Vagg MJ \& Payne JM 1970 The effect of ammonium chloride induced acidosis on calcium metabolism in ruminants. British Veterinary Journal 126 530-537

Vagnoni DB \& Oetzel GR 1998 Effects of dietary cation-anion difference on the acid-base status of dry cows. Journal of Dairy Science $\mathbf{8 1}$ 1643-1652

Wiggers KD, Nelson D \& Jacobson NL 1975 Prevention of parturient paresis by a low-calcium diet prepartum: a field study. Journal of Dairy Science 58 430-431 